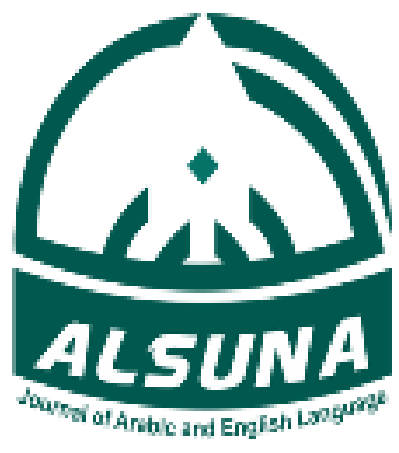

\title{
The Implementation of Contextual Teaching and Learning on English Grammar Competence
}

\author{
Imam Nur Aziz ${ }^{1}$, Yuli Ani Setyo Dewi² \\ ${ }^{1}$ Institut Keislaman Abdullah Faqih Gresik \\ ${ }^{2}$ STITNU AL-HIKMAH \\ (1imamnuraziz@gmail.com, 2yulianisetyo85@gmail.com)
}

Approved: 2019-12-07

Key Words:

Teaching Grammar

CTL

Language Teaching

\section{ABSTRACT}

The research aims to the effectiveness of Contextual Teaching and Learning (CTL) in teaching grammar. A quasi-experimental Non-randomize study of the pretest-posttest is used in this research. The research is carried out at SMP NU Bahrul Ulum Menganti Gresik, in which 37 as the experimental group and 41 as a control group. The validity test is calculated using the biserial point correlation, and the reliability test is 0.848 which is calculated by using the K-R 21 formula. In analyzing the data, the researcher used ANCOVA. The result shows that the average score of the pretest was 60,95 for the experimental group and 60,00 for the control group. The average score of the posttest was 85,95 for the experimental group and 78,9 for the control group. The calculation of ANCOVA found that the value of $F$ is 8.7 and F critical with df 76 at 0.01 level of significance 6.96. It means that $F$ value was higher the F critical. The result of data analysis showed that Contextual Teaching and Learning (CTL) give an effect on teaching grammar for 7 th-grade students of junior high school.

\section{Introduction}

English teaching and learning have become much more demanding for teachers, students, and also our next generation (Aziz, "Curriculum Development of KKNI at English Education Department of INKAFA Gresik"). Since then, English is simplified in the scope of Indonesian society since many institutions apply a bilingual program for students they teach. Furthermore, when Indonesia Education System implements KTSP

Imam Nur Aziz, Yuli Ani Setyo Dewi

The Implementation of Contextual Teaching and Learning on English Grammar Competence
ALSUNA Vol. 2 (2), 2019

http://e-journal.ikhac.ac.id/index.php/alsuna https://doi.org/10.31538/alsuna 
(Kurikulum Tingkat Satuan Pendidikan) as the curriculum for all education layers in Indonesia, English is taught since Elementary school as an additional subject. Having communicative competence means that the students have to understand and express the information, thinking and minds (Gudu) in their daily life because each student has the covert ability in developing language. (Brown) States that English is sometimes a required secondary school subject and almost always one of the several foreign language options. So, teaching English is continuous to the level of junior high school and senior high school (secondary schools). There, English is taught as the primary subject that has been decided by the government. In higher education level, tertiary education, English is taught as a General Basic Course (Mata Kuliah Dasar umum) across study programs (Amalia). And beginning from junior high school, grammar material subject is taught as the early stage in mastering English. Especially in mastering and improving students' grammar competency.

On the other hand, we find a phenomenon that students in the early stage have less in understanding and practicing grammar as their first stage in mastering English (Yani; Silviana and Putri). They prefer to learn English by themselves without caring for the grammatical words or sentences they learn. Another serious phenomenon which causes the intelligence derivation of Indonesian students in mastering English grammar is the using of the conventional method in the language classroom (Marcellino) as we know that English teaching in KTSP has some Competency Standards (Standar Kompetensi) and Basic Competency (Kompetensi Dasar) (Hakim) in four chapters that include four skills for each semester. English teachers must carry out all their materials based on the persist of the used curriculum before the time is over.

Imam Nur Aziz, Yuli Ani Setyo Dewi

The Implementation of Contextual Teaching and Learning on English Grammar Competence
(68)

http://e-journal.ikhac.ac.id/index.php/alsuna https://doi.org/10.31538/alsuna 
Contextual teaching and learning (CTL) is a constructivist concept of education and learning (Fitriani et al.; Rafida). Instruction takes place when teachers can demonstrate knowledge in such a manner that students can create meaning from their personal experiences. Contextual education experiences include an internship, maintenance education, and study abroad programs. Constructivist learning theory maintains that teaching is the process of building thought from experiences contextual learning may be helpful for students (Richardson) if it allows teaching experiences in the setting in which students are interested and motivated. Several empirical learning theorists have led to an understanding of contextual education.

Contextual teaching and learning is the way of education that can't be divided with behaviorism and constructivism theories (Ertmer and Newby). This concept of education and learning helps teachers relate content knowledge to real-life conditions and its use to their lives as a home, citizen, and workers and engage in the difficult work that education needs. The concept emphasizes students' share and education. Overall, contextual teaching and learning is the approach that concentrates on the students' middle. Because both theories of behaviorism and constructivism allow primary education in the teaching and learning process (Weegar and Pacis). In the case, these position of behaviorism and constructivism theories associated with this process of discourse teaching and learning were behaviorism as the way for approach that students' noticeable behaviors when they got aside in teaching and learning process while constructivism as the way to help students connect the content could be used (Jones and Brader-Araje; Ertmer and Newby; Weegar and Pacis). This is the reason why CTL has this abbreviation of contextual teaching and education because of the process from experiences environment.

Imam Nur Aziz, Yuli Ani Setyo Dewi

The Implementation of Contextual Teaching and Learning on English Grammar Competence

1
(69)

http://e-journal.ikhac.ac.id/index.php/alsuna https://doi.org/10.31538/alsuna 
CTL requires making teaching relevant to students by connecting to the real-life (Kalchik and Oertle; Baker et al.; Fitriani et al.). It draws upon students' different accomplishments, pursuits, experiences, and civilizations and incorporates these into what and how students see and how they are valued. CTL method is proved to be a trend of recalling to an assumption that learning will be meaningful if learners can connect the learning content with the real context of the surrounding environment (Levy). Educator Elaine B. Johnson explains that Meaning emerges from the relationship between content and its context (Elaine B). Context gives meaning to content. The broader the context within which students are able to make connections, the more meaning content will hold for them (Elaine B). Considering the characteristics of the CTL method, there is an expectation that this English learning method will be able to give a good and positive contribution towards English teaching and learning, particularly in improving students' competency in mastering and practicing English grammar.

Traditionally, language education has focused on learning grammar in the sentence point. Sentence-level grammar refers to components pf words, tenses, phrases, clauses, and language rules (Aziz, "Developing English Reading Book For College Students of INKAFA Based on Monitoring Strategy"). Nevertheless, new education approaches acknowledge that it is important to consider grammar in context. In other words, it's one thing to see the grammatical component at specific instances or to be able to select the right kind in the grammar activity. For centuries, the choice approach to learning grammar mostly consists of studying grammar principles, studying grammar language, learning paradigms, and establish grammatical quality. In this case, the researcher focuses on teaching grammar by using CTL at students of SMP NU Bahrul Ulum Menganti Gresik, especially for seventh grade. The students feel that their grammar

Imam Nur Aziz, Yuli Ani Setyo Dewi

The Implementation of Contextual Teaching and Learning on English Grammar Competence

1
ALSUNA Vol. 2 (2), 2019

http://e-journal.ikhac.ac.id/index.php/alsuna https://doi.org/10.31538/alsuna 
is too less. Because they have a good strategy in learning grammar, the teachers also do not give any good methods. Therefore, they get difficulties in mastering English grammar. Recently, the CTL method is proved to be a trend of recalling to an assumption that learning will be meaningful if learners are able to connect the learning content with the real context of the surrounding environment. Educator Elaine B. Johnson explains, "Meaning emerges from the relationship between content and its context. Context gives meaning to content. The broader the context within which students are able to make connections, the more meaning content will hold for them (Elaine B)."

\section{Research Problem and Objective of The STUDY}

This research can be divers the fact that concerns about observational as follow: Do students in the seventh grade of SMP NU Bahrul Ulum Gresik who taught grammar using the CTL method had a better score than those who were taught by the conventional method?. To know the grammar achievement of seventh-grade students who were taught by using CTL had a better score than they who were taught by using a conventional method.

\section{Contextual Teaching and Learning (CTL)}

(Berns and Erickson) Explain that a national conversation has emerged in recent years regarding the best way of teaching to attain higher student achievement, especially in language teaching. Many educators try to create an effective method in language teaching because invariable learning activities may cause boredom for young learners (Setiawan and Mitra Zuana). Then, as direct instruction followed by practicing specific skills,

Imam Nur Aziz, Yuli Ani Setyo Dewi

The Implementation of Contextual Teaching and Learning on English Grammar Competence
(71)

http://e-journal.ikhac.ac.id/index.php/alsuna https://doi.org/10.31538/alsuna 
contextual teaching and learning (CTL) provide a constructivist model of teaching language, which is not aside from teaching grammar.

Contextual teaching and learning is a conception of teaching and learning that helps teachers relate subject matter content to real-world situations; and motivates students to make connections between knowledge and its applications to their lives as family members, citizens, and workers and engage in the hard work that learning requires (Berns and Erickson). Contextual Teaching and Learning (CTL) is a learning system that matches the performance of the brain to develop patterns that create meaning by linking academic content to the context of the everyday life of learners (Chen and Schmidtke). So, CTL (Contextual Teaching and Learning) is applied in the language learning process by giving an example which is adjusted and connected with students' real situation in life context. (Berns and Erickson) Also, conclude that CTL helps students connect the content they are learning to the life contexts in which that content could be used. Students then find meaning in the learning process. As they strive to attain learning goals, they draw upon their previous experiences and build upon existing knowledge. From their conclusion of the observation, it answers apart to the great question about the effectiveness of Contextual Teaching and Learning (CTL) in language teaching, especially in teaching grammar. CTL is called a contextual approach because the concept of learning helps teachers to link between the content to be studied with real-world situations of students and encourages students to make connections between the knowledge possessed by its application in their lives as members of society (Faridi).

It summarizes that CTL as a holistic education process whose purpose is helping learners to understand the meaning of subject matter is interesting method by connecting the material with students' daily life context (personal, social and cultural context), that

Imam Nur Aziz, Yuli Ani Setyo Dewi

The Implementation of Contextual Teaching and Learning on English Grammar Competence
(72)

http://e-journal.ikhac.ac.id/index.php/alsuna https://doi.org/10.31538/alsuna 
the learners have a knowledge or skill which is able to be transferred flexibility from one problem to another problem. Contextual teaching is teaching that enables students to reinforce, expand, and apply their academic knowledge and skills in a variety of in-school and out-of-school settings in order to solve simulated or real-world problems. Contextual learning occurs when students apply and experience what is being taught referencing real problems associated with their roles and responsibilities as family members, citizens, students, and workers. Contextual teaching and learning emphasize higher-level thinking, knowledge transfer across academic disciplines, and collecting, analyzing and synthesizing information and data from multiple sources and viewpoints (Nurhadi and Yasin).

Johnson in Nurhadi explains that CTL is making a meaningful connection, doing significant work, self-regulated learning, collaborating, critical and creative thinking, nurturing the individual, reaching high standards, and using authentic assessment. It clearly states that CTL is student-centered and emphasizes students' capable of activating their language learning process.

CTL has some different principles from others. (Elaine B) States that CTL encompasses three typical principles, they are the principle of interdependence, the principle of differentiation, and the principle of self-organization. CTL challenges the students to respect that uniqueness, diversity, and creativity by collaborating in a searchgroup of meaning, insight, and a fresh perspective and to realize that diversity as a sign of robustness and strength (Elaine B). He also argues that CTL system is an educational process that aims to help students see meaning in the academic material they are studying by connecting academic subject with the context of their lives, that is, with the context of their personal, social, and cultural circumstance by seven components; constructivism,

Imam Nur Aziz, Yuli Ani Setyo Dewi

The Implementation of Contextual Teaching and Learning on English Grammar Competence

1
ALSUNA Vol. 2 (2), 2019

http://e-journal.ikhac.ac.id/index.php/alsuna https://doi.org/10.31538/alsuna 
questioning, inquiry, learning community, modeling, reflection, and authentic assessment.

\section{The Characteristics of CTL}

According to (Elaine B) there are eight characteristics in CTL system. They are as follows: 1) Making a meaningful connection. Students can manage themselves as the learners who learn actively in developing their interest individually, the learners who can do by themselves or work in a group, and the learners who can do learning by doing. 2) Doing significant work. Students make relations of school and all contexts in their reallife as the business subject and as a member of society. 3) Self-regulated learning. Students do the significant work: there is the purpose, the affair to the other, the relation to a decision of choice, and the obvious result. 4) Collaborating. Student can do collaborating. The teacher helps them to work effectively in the group, helps them to understand how they will influence and communicate with one another. 5) Critical and Creative Thinking. Students can use a higher level of thinking critically and creatively. So, they can analyze, make synthetics, solve a problem, make a decision, and use logic and evidence. 6) Nurturing the individual. Students nurture their individual by taking care of their private as knowing, giving attention, having high expectations, motivating and straightening themselves. In this characteristic, students need much supporting. They will not be the successful one when their parents or their adult persons do not give any support for them. And the next, to nurture the individual, students have to respect their friends and also the adult people. 7) Reaching high standards. The purpose of this characteristic is that students can know and reach a high standard. The teacher's duty here is identifying the objective and motivating students to achieve their objective of the study. The teacher shows the students a way to get it in the best way called "excellence." 8) Using authentic

Imam Nur Aziz, Yuli Ani Setyo Dewi

The Implementation of Contextual Teaching and Learning on English Grammar Competence

1
(74)

http://e-journal.ikhac.ac.id/index.php/alsuna https://doi.org/10.31538/alsuna 
assessment. In using authentic assessment, the students use their academic knowledge to their real-world context for a meaningful purpose. For example, the students are permitted to illustrate the academic information that they have learned in English lessons by planning the menu of activities, both inside and outside of the school area.

It is clearly stated that CTL is student-centered and emphasizes students' capable of activating their language learning process. On the other hand, there are also characteristics of the teacher who uses CTL in language instruction. In her book, Elaine states that the good teachers who use CTL have two characteristics. Firstly, they know and respect the materials they teach. Every academic purpose which they hope can be mastered by the students has been mastered by them beforehand. Secondly, the teachers give attention to their students by affection and kindness of heart, honestly. Both of these two qualities, teachers, have some roles as the mentor and an expert. So those rules conducive CTL teachers to change their students' life (Elaine B).

\section{The Principles of CTL}

CTL has some different principles from others. CTL encompasses three typical principles, they are the principle of interdependence, the principle of differentiation, and the principle of self-organization. The principle of interdependence states that all things both in and out of the schools are interconnected that creates a learning environment. The schools are built in societies. Students, parents, teachers, principals, administration staff, gardeners are from societies. The output the schools will be back in society too. The principle of interdependence connects everything in the universe to everything else. It requires connecting, collaborating, thinking actively and creatively, engaging in handson learning, formulating clear objectives, identifying high standards, doing significant

Imam Nur Aziz, Yuli Ani Setyo Dewi

The Implementation of Contextual Teaching and Learning on English Grammar Competence
(75)

http://e-journal.ikhac.ac.id/index.php/alsuna https://doi.org/10.31538/alsuna 
tasks that benefit others, valuing each person and using assessment methods that link learning with the real world.

The principle of differentiation is related to the uniqueness and differences of each student. It frees students to explore their individual talents, cultivates their own learning style, and progress at their own pace. CTL challenges the students to respect that uniqueness, diversity, and creativity by collaborating in a group in search of meaning, insight, and a fresh perspective, and to realize that diversity as a sign of robustness and strength.

The principle of self-organization enables the students to develop their potentials, achieve academic excellence, and have career skills by connecting school work with their prior experience and knowledge. They are responsible for what they are doing. The decision will be made after planning and evaluating the evidence critically. The collaboration with others is conducted to gain new insight and to enlarge their perception. Furthermore, Nurhadi and Senduk state that to implement CTL for students, the teacher must use the following principles: a) Developmentally Appropriate. In constructing methodology and curriculum content, a teacher must consider students' age, emotion, social condition, and the development of students' intelligence. b) Independent Learning Groups. Students work in small groups, take and give, and cooperate. Just like the adult, when they are working, they cannot work alone. They need friends and work in terms. c) Self-regulated Learning. School, social support and guides students to reach aspiration. Diversity of students in teaching and learning process, the teacher considers students' background; their religion, tribe, social economy, mother tongue, and weakness. d) Diversity of students. In the classroom, the teacher must teach the students by all their varieties. For example, the background of nation ethnics, the status of social-economics,

Imam Nur Aziz, Yuli Ani Setyo Dewi

The Implementation of Contextual Teaching and Learning on English Grammar Competence

1
(76)

http://e-journal.ikhac.ac.id/index.php/alsuna https://doi.org/10.31538/alsuna 
the main language they use in the home, and all flaws that are possible they have. Thus, it is hoped that the teacher can help students to reach the objective of the study. e) Multiple Intelligences. Because of the students' multiple intelligence, the teacher must be creative to find an appropriate strategies for their students. f) Questioning. Questions are designed to stimulate critical and creative thinking. It also designed to increase students' learning, develop problem solving, and make a high level of thinking skill. g) Authentic Assessment. The assessment is based on the participation and performance of how students apply knowledge in the process of learning, not memorizing (Nurhadi and Yasin).

Johnson argues that CTL system is an educational process that aims to help students see meaning in the academic material they are studying by connecting the academic subject with the context of their lives, that is, with the context of their personal, social, and cultural circumstance (Elaine B). To achieve this aim, the system encompasses seven components as follows: constructivism, questioning, inquiry, learning community, modeling, reflection, and authentic assessment.

\section{The Main Feature of CTL}

In its concept, learning using CTL has a feature that becomes the main symbol of CTL. And it is also a distinctive feature between CTL and other methods that are used to achieve the objective of the study. In her book, Elaine B. Johnson decelerates that discovery meaning is the main feature of CTL. In a dictionary, "Meaning" is interpreted as "The important meaning of something or purpose." When the students are asked to learn a thing that has no meaning, they will be inquisitive about why they must learn it. Unconsciously, they begin to look for the meaning from the question they create, looking

Imam Nur Aziz, Yuli Ani Setyo Dewi

The Implementation of Contextual Teaching and Learning on English Grammar Competence
(77)

http://e-journal.ikhac.ac.id/index.php/alsuna https://doi.org/10.31538/alsuna 
for the important meaning and purpose, and also the users of the assignment they accept. At this point, meaning finding is a natural thing that often appears without any conscious by the subject. Contextual Teaching and Learning is Neurology ascertain the existence of a brain's need to find meaning. The brain tries to give the mean for new information by connecting it to the available knowledge and skill. When we are asked to do something we never do before, at that moment we try to think back, do we ever experience the same thing or no. The brain tries to connect the new assignment to the other assignment we have known.

In looking for and finding meaning, the brain has the main role as the activator to fulfill its need in understanding new information that accepted. In the quotation above, Elaine gives a simple illustration of how the brain's works to look for, find and connect new information to the information that has been known before. Brain's work to look for, find and connect new school assignments students accept to the other assignment they have accepted. This will be a good way for them to understand the new material they accept with easier.

\section{Dissimilarity Between CTL and Conventional Method}

Many people don't know the dissimilarity between CTL and other methods which is usually applied by an institute in language learning. They tend to have a notion that CTL has no significant dissimilarity with the conventional method which is usually used. Here, the researcher will flatten the dissimilarity both of them. Besides to justify the perception of ones who don't understand CTL well, the researcher also illustrate a different illustration about CTL's unique in language learning process. The dissimilarities both of them are illustrated in the following:

Imam Nur Aziz, Yuli Ani Setyo Dewi

The Implementation of Contextual Teaching and Learning on English Grammar Competence
(78)

http://e-journal.ikhac.ac.id/index.php/alsuna https://doi.org/10.31538/alsuna 


\section{CTL Method}

a) Students have engaged in the learning process actively.

b) Students study from their friends by a group working, discussion, correcting one another.

c) Learning is fastened upon the real-life and or simulated.

d) The behavior is constructed based on self-awareness.

e) Skill is developed based on comprehension.

f) The reward for good behavior is self-satisfaction.

g) Someone does not do a bad thing because he/she is aware that it is wrong and harm.

h) Language is taught communicatively, that is students are invited to use language in the real context.

i) Students' comprehension is developed based on what has been available in students' selves.

j) Students use thinking ability critically, engaged in striving for the happening of an effective learning process, join in control of the happening of an effective learning process and bring each comprehension in the learning process.

k) Their own selves develop human beings' knowledge. They are created or construct knowledge by giving meaning and understanding their experience.

1) Because knowledge is developed by themselves, while they always experience new events, so, that knowledge develops.

m) Students are asked to monitor and develop their every learning responsibly.

n) The appreciation for students' experience has too major.

o) Learning yield is measured in various ways: processing, working, work product, performance, record, test, etc.

p) Learning is able to happen in various places, contexts, and settings.

q) Remorse is a kind of punishment of bad behavior.

r) Good behavior is based on intrinsic motivation.

s) Student-centered.

t) Someone does a good thing because of he/she certain that it is the best and useful.

\section{Conventional Method}

a) Students as an information receiver passively.

b) Students study individually.

c) Learning is too abstract and theoretical.

Imam Nur Aziz, Yuli Ani Setyo Dewi

The Implementation of Contextual Teaching and Learning on English Grammar Competence
(79)

http://e-journal.ikhac.ac.id/index.php/alsuna https://doi.org/10.31538/alsuna 
d) The behavior is constructed based on habit.

e) Skill is developed besed on the training.

f) The reward for good behavior is rapport praise (rate).

g) Someone does not do a bad thing because he/she is afraid of punishment.

h) Language is taught structurally: the formula is explained to understand and then trained.

i) Students' comprehension is out of students' selves, which must be explained, received and memorized.

j) Students receive the formula or comprehension (reading, listening, noting, memorizing) passively without giving an idea contribution in the learning process.

k) Knowledge is detention to a series of fact, concept, or law which is available outside human beings' selves.

1) Its character is absolute and final.

$\mathrm{m})$ The teacher is a determiner of the way of the learning process.

n) Learning does not pay attention to students' experience.

o) Learning yield is only measured by the yield of the test.

p) Learning has only happened in the scope of the classroom.

q) A sanction is a kind of punishment for bad behavior.

r) Good behavior is based on extrinsic motivation.

s) Teacher-centered.

t) Someone does a good thing because he/she is accustomed to doing it. This habit is constructed by giving the gratify reward.

\section{Research Design}

This research involved the student of seventh-grade Bahrul Ulum Menganti Gresik by using Quasi-Experimental design non-randomize sampling. The researcher took the students in the seventh grade of SMP NU Bahrul Ulum Menganti Gresik as the population of this research, which had five parallel classes. Then, for the sample of this research, the researcher chose two classes as the experimental group and the control group. And the sample the researcher took was the students of $\mathrm{VII}^{\mathrm{A}}$ and $\mathrm{VII}^{\mathrm{B}}$ class. In selecting the sample, the researcher used non-Random Assign as the technique. The result

Imam Nur Aziz, Yuli Ani Setyo Dewi

The Implementation of Contextual Teaching and Learning on English Grammar Competence
(80)

http://e-journal.ikhac.ac.id/index.php/alsuna https://doi.org/10.31538/alsuna 
was consulted with a critical score for the Point Biserial Correlation. So, to calculate the validity of the test, the researcher used the formula as follows:

$$
\mathrm{r}_{\mathrm{pbi}}=\frac{\mathrm{M}_{\mathrm{p}}-\mathrm{M}_{\mathrm{t}}}{S D_{\mathrm{t}}} \sqrt{\frac{\mathrm{p}}{q}}
$$

To give the interpretation to $\mathrm{r}_{\mathrm{pbi}}$, we need " $\mathrm{r}$ " Product Moment Table by looking for the $\mathrm{df}(\mathrm{df}=\mathrm{N}-\mathrm{nr})$ firstly. If $\mathrm{r}_{\mathrm{pbi}}$ that we got in the counting was the same or higher than rtable, so, we could conclude that the correlation of two variables we looked for was correlating significantly. If $r_{p b i}$ was lower than $r_{\text {table, }}$ it meant that there was no significant correlation. For the calculating of validity items, it was shown in appendix 2 and 3. And the table of "r" Product. To calculate and to measure the reliability of pre-test and posttest, the researcher used the formula of Kuder-Richardson 21 as follows:

$$
r_{x x}=\frac{K \sigma x^{2}-\bar{X}(K-\bar{X})}{\sigma x^{2}(K-1)}
$$

The degree to which a test was consistent or reliable, could be estimated by calculating a reliability coefficient $\left(r_{x x}\right)$. A reliability coefficient could go as high as +1.00 for a perfectly reliable test and could only go as low as 0.00 .

$$
\begin{aligned}
r_{x x}= & \frac{K \sigma x^{2}-\bar{X}(K-\bar{X})}{\sigma x^{2}(K-1)} \\
& =\frac{(50) 8.1^{2}-25 \cdot 9(50-25.9)}{8.6^{2} \cdot(50-1)} \\
& =\frac{(50) 73,96-(25.9) \cdot(24.1)}{(73.96) \cdot(49)} \\
& =\frac{3698-624 \cdot 19}{3624.04} \\
& =\frac{3073.81}{3624.04}=0.848
\end{aligned}
$$

Imam Nur Aziz, Yuli Ani Setyo Dewi

The Implementation of Contextual Teaching and Learning on English Grammar Competence
ALSUNA Vol. 2 (2), 2019

(81)

http://e-journal.ikhac.ac.id/index.php/alsuna https://doi.org/10.31538/alsuna 
Item of discrimination power was used to know how accurate the question differs from the higher subject and lower subject. Then, to calculate the index of discriminating power, the researcher used the formula as follow:

ANOVA analysis test that is:

$$
\mathrm{D}=\frac{\mathrm{Ru}-\mathrm{Rl}}{1 / \mathrm{R}^{\mathrm{T}}} \times 100
$$

$$
\begin{aligned}
& \underline{\left(\sum X\right)^{2}} \\
& \text { 1. } \mathrm{SS}_{\mathrm{t}}=\Sigma \mathrm{X}^{2}-\quad N \\
& =536875-\frac{(6415)^{2}}{78} \\
& =536875-\frac{41152225}{78} \\
& =536875-527592.63 \\
& =9282.37 \\
& \text { 2. } \mathrm{SS}_{\mathrm{b}}= \\
& \frac{\left(\sum X_{1}\right)^{2}}{n_{1}}+\frac{\left(\sum X_{2}\right)^{2}}{n_{2}}-\frac{\left(\sum X\right)^{2}}{N} \\
& =\left[\frac{3180^{2}}{37}+\frac{3235^{2}}{41}\right]-\frac{6415^{2}}{78} \\
& {\left[\frac{10112400}{37}+\frac{10465225}{41}\right]-\frac{41152225}{78}} \\
& \text { 3. } \mathrm{SS}_{\mathrm{w}}=\mathrm{SSt}-\mathrm{SSb} \\
& =9282.37-964.87 \\
& =8317.5 \\
& \text { 4. } \mathrm{MS}_{\mathrm{b}}=\frac{S S b}{K-1} \\
& =\frac{964.87}{2-1} \\
& =\frac{964.87}{1} \\
& =964.87 \\
& \text { 5. } \mathrm{MS}_{\mathrm{w}}=\frac{S S w}{N-K} \\
& =\frac{8317.5}{78-2} \\
& =\frac{8317.5}{76} \\
& =109.44 \\
& \text { 6. } \mathrm{D}_{\mathrm{fb}}=\mathrm{K}-1 \\
& =2-1 \\
& =1 \\
& \text { 7. } D_{\mathrm{fw}}=\mathrm{N}-\mathrm{K} \\
& =78-2 \\
& {[273308.11+255249.39]-527592.63} \\
& =528557.5-527592.63 \\
& =76 \\
& =964.87
\end{aligned}
$$

The result of the value of SSt is $9282.37, \mathrm{SSb}$ is $964.87, \mathrm{SSw} 8317.5, \mathrm{MSb}$ is 964.87 , and MSw is 109.44. To know the correlation between covariate variable data and dependent variable data in the whole of the subject (rt) and each group (rk). The researcher calculates:

Imam Nur Aziz, Yuli Ani Setyo Dewi

The Implementation of Contextual Teaching and Learning on English Grammar Competence
ALSUNA Vol. 2 (2), 2019

(82)

http://e-journal.ikhac.ac.id/index.php/alsuna https://doi.org/10.31538/alsuna 
1. $S X$

$\mathrm{SY}_{1} \quad=\sqrt{\frac{\sum Y_{1}^{2}}{n_{1}}}-\bar{Y}_{1}^{2}$

r1

$=\sqrt{\frac{143825}{37}}-(60.95)^{2}$

$=\sqrt{\frac{143825}{37}}-3714.90$

$=\sqrt{3887.16-3714.90}$

$=\sqrt{172.26}$

$=13.12$

$\underline{\sum X_{1} Y_{1}}-\overline{X_{1} Y_{1}}$

$=\frac{n_{1}}{S X_{1} \cdot S Y_{1}}$

$=$

194925

37

(10.74).(13.12)

$5268.24-5238.6525$

140.91

$=\frac{29.59}{140.91}$

$=0.21$

2. $\mathrm{SX}_{2} \quad=\sqrt{\frac{\sum X_{2}^{2}}{n_{2}}}-{\overline{X_{2}}}^{2}$ $=\sqrt{\frac{259275}{41}-(78.9)^{2}}$

$=\sqrt{\frac{259275}{41}-6225.21}$

$=\sqrt{6323.78-6225.21}$

$=\sqrt{98.57}$

$=9.93$

$\mathrm{SY}_{2}=\sqrt{\frac{\sum Y_{2}^{2}}{n_{2}}}-{\overline{Y_{2}}}^{2}$

$=\sqrt{\frac{155000}{41}}-(60)^{2}$

$=\sqrt{\frac{155000}{41}}-3600$

$=\sqrt{3780.49-3600}$

$=\sqrt{180.49}$

$=13.43$

$\underline{\sum X_{2} Y_{2}}-\overline{X_{2}} \overline{Y_{2}}$

$\mathrm{r} 2$

$=\frac{n_{2}}{S X_{2 .} S Y_{2}}$

$\frac{\frac{195600}{41}-(78.9) .(60)}{}$

(9.93).(13.43)

$=\frac{4770.73-4734}{133.36}$

$=\frac{36.73}{133.36}$

$=0.28$

3. SX

$=\sqrt{\frac{\sum X^{2}}{N}}-\overline{X^{2}}$

$=\sqrt{\frac{536875}{78}}-(82.24)^{2}$

$=\sqrt{\frac{536875}{78}}-6763.42$

$=\sqrt{6883.01-6763.42}$
Imam Nur Aziz, Yuli Ani Setyo Dewi

The Implementation of Contextual Teaching and Learning on English Grammar Competence
ALSUNA Vol. 2 (2), 2019

(83)

http://e-journal.ikhac.ac.id/index.php/alsuna https://doi.org/10.31538/alsuna 


$$
\begin{aligned}
& =\sqrt{119.59} \\
& =10.94 \\
S Y=\sqrt{\frac{\sum Y^{2}}{N}}-\overline{Y^{2}} & \\
& =\sqrt{\frac{298825}{78}}-(60.45)^{2} \\
& =\sqrt{\frac{298825}{78}}-3654.20 \\
& =\sqrt{3831.09-3654.20} \\
& =\sqrt{176.89} \\
& =13.3
\end{aligned}
$$

$$
\begin{aligned}
\mathrm{rt} \quad & =\frac{\sum X Y}{N}-\overline{X Y} \\
& = \\
\frac{\frac{390525}{78}-}{S X Y S Y} & (82.24) \cdot(60.45) \\
(10.94) \cdot(13.3) & \frac{390525}{78}-4971.41 \\
& =\frac{145.50}{145.50} \\
& =\frac{5006.73-4971.41}{145.50} \\
& =\frac{35.32}{145} \\
& =0.24
\end{aligned}
$$

The result shows that the value of the covariate data for the entire subject (rt) is 0.24 , and the value of the covariate data for each group (rk) in $\mathrm{r}_{1}$ is 0.21 , and $\mathrm{r}_{2}$ is 0.28 . The researcher adjusts (re-analyzing) the values of SSt, SSw, SSb, MSw, and MSb from ANOVA by removing the covariate variable's effect on the dependent variable. And they are calculated by the counting as below:

1. SS`t

2. SS`w

$$
\begin{aligned}
\text { Rw } \quad & =\frac{r 1+r 2}{2} \\
& =\frac{0.21+0.28}{2} \\
& =\frac{0.49}{2} \\
& =0.24 \\
& =8317.59\left(1-0.24^{2}\right) \\
\text { SS }{ }^{\prime} \mathrm{S} & =8317.59(1-0.0576)
\end{aligned}
$$

$$
\begin{aligned}
& =(8317.59) .(0.9424) \\
& =7838.41 \\
& =S^{`}{ }^{\prime}-S S^{`} \mathrm{w} \\
& =8747.71-7838.41 \\
& =909.3 \\
& =\frac{S S^{`} b}{k-1} \\
& =\frac{909.3}{1} \\
& =909.3 \\
& =\frac{S S ` w}{N-k-1} \\
& =\frac{7838.41}{75} \\
& =2.54
\end{aligned}
$$$$
\text { 5. MS }{ }^{`} \mathrm{w}=\frac{S S^{`} w}{N-k-1}
$$

Imam Nur Aziz, Yuli Ani Setyo Dewi

The Implementation of Contextual Teaching and Learning on English Grammar Competence
ALSUNA Vol. 2 (2), 2019

(84)

http://e-journal.ikhac.ac.id/index.php/alsuna https://doi.org/10.31538/alsuna 

6. $\mathrm{F}$
$=\frac{M S^{`} b}{M S^{`} w}$
$=8.7$
$=\frac{909.3}{104.51}$

The final data shows that value SS ${ }^{\prime} t$ is $8747.71, S^{`}{ }^{\prime} w$ is 7838.41 , is 909.3, MS $^{\prime} \mathrm{w}$ is 104.51, and the value of MS $\mathrm{b} b$ is 909.3 .

\section{Testing Hypothesis}

At this point, the researcher does the last step of analyzing the data, which is a testing hypothesis. After doing some calculations of ANCOVA as above, it is found out the result that the F value is 8.7. Then, it is checked out in the table of $F$, and there is found that F critical score with df 76 (the whole number of students in the experimental and control group - the number of groups) at $1 \%$ level of significance is 6.96. It interprets that $\mathrm{F}$ value is higher than F critical score. The result of ANCOVA with pretest as a covariate is showed in the table as below:

The Simple Conclusion Result of F Value

\begin{tabular}{ccc|} 
F value & Result & F critical score \\
\hline $\mathbf{8 , 7}$ & $>$ & 6,96 \\
\hline
\end{tabular}

Summary of ANCOVA with Pre-test and Post-Test as Covariate

\begin{tabular}{|l|l|l|l|l|l|}
\hline \multicolumn{1}{|c|}{ Source of Variance } & \multicolumn{1}{|c|}{ SS } & Df & \multicolumn{1}{|c|}{ MS } & F & \multicolumn{1}{c|}{ Level of significance } \\
\hline Between group & 909.3 & 1 & 909.3 & 8.7 & $1 \%$ \\
\hline Within group & 7838.41 & 76 & 104.51 & & \\
\hline Total & 8747.71 & \multicolumn{5}{|l}{} \\
\hline
\end{tabular}

Based on the result of students' scores from data analysis above, it is concluded that there is a significant difference in students' grammar achievement who are taught by

Imam Nur Aziz, Yuli Ani Setyo Dewi

The Implementation of Contextual Teaching and Learning on English Grammar Competence
ALSUNA Vol. 2 (2), 2019

http://e-journal.ikhac.ac.id/index.php/alsuna https://doi.org/10.31538/alsuna 
using CTL method and those who are taught by using the conventional method. It is because the students who are taught using CTL have a better score than those who are taught using conventional method. Then, it gives an interpretation that the null hypothesis is rejected and the alternative hypothesis is accepted.

\section{Discussion}

Based on the computation result of data analysis, it could be explained that the Contextual Teaching and Learning (CTL) method is more effective than the conventional method. Firstly, Although the experimental has a little bit higher score than the control group, which is proven from the result of the average pretest score, and both of the two groups are seen similar in the early step, but in the next step they show the distinctive in accepting the material. It is proven during the process of the study, the researcher knows when the students who taught using the Contextual Teaching and Learning method are enthusiastic about studying and learning more about English. They try to build their competency in accepting the material by searching, observing and analyzing with their critical and creative thinking. While the control group only accept the material from the teacher's explanation and it is based on their textbook. In other words, teaching grammar process using CTL in the experimental group is based on student-centered, because they can build themselves by searching, observing and analyzing the material. While the process of teaching grammar using a conventional method in the control group is called teacher-centered because the students only laid on the teacher's explanation in front of the class, it made their comprehension about English is limited on their teacher explanation and the textbook.

Imam Nur Aziz, Yuli Ani Setyo Dewi

The Implementation of Contextual Teaching and Learning on English Grammar Competence
(86)

http://e-journal.ikhac.ac.id/index.php/alsuna https://doi.org/10.31538/alsuna 
Secondly, the method of Contextual Teaching and Learning in teaching grammar gives opportunities for students to understand the passages and materials through their real experiences and activities. The students who taught using CTL learned the grammar material better when the situation around them is created naturally, and they relate it to what they get in the school. It was more meaningful when they learned about their experiences. CTL also produces the students who do not only know about what they learn or memorize what the teacher considered but also creating a setting in which they learned realistically. On the other hand, the procedures in the control group are assumed as dull and unattractive. Some of the students are bored, talking with their friend, lazy and loss of concentration in the middle of the learning process because the primary attention is directed on the teacher's explanation. Unfortunately, the students can not develop and practice their learning interest in learning Grammar. Those happened because their activities controlled and dictated by the teacher so they could not improve their learning activities free.

The classroom activities are adjusted to the learning process. In this study, the material is taken from the student's handbook (LKS) and another source. The activity and assessment of the Experimental group are based on the other interesting way. One of the interesting activities of the Experimental group is that they are given authentic instruction from the teacher. In this case, the students are given a text made based on their context. Then, students are asked to read, find, and analyze the formula, pattern, and usage of sentences in the text which used the tenses of the grammar topic. Then, the students are asked to observe, gather data, and draw the conclusion about the topic and also found the meaning and aim of sentences on the text and connect it to their life context. Then, every student is asked to make some sentences about the grammar topic based on their daily

Imam Nur Aziz, Yuli Ani Setyo Dewi

The Implementation of Contextual Teaching and Learning on English Grammar Competence

1
(87)

http://e-journal.ikhac.ac.id/index.php/alsuna https://doi.org/10.31538/alsuna 
experience and also united them into a simple paragraph. And they have to analyze the formula of the sentences they made by themselves. After that, the students are given into some small groups to work and understand the passage of grammar topics. And every group has to make questions about the grammar topic, which they do not understand while the teacher answers and explains the question by giving examples based on students' daily context. On the other hand, every student of the other group listened to the other groups' questions and answers to the topic well. The last, the students review and resumed the answer to their events, experiences, and activities orally in front of the class.

Moreover, students who are taught using Contextual Teaching and Learning method would have critical and creative thinking so that the students will have a higher level of thinking critically and creatively by analyzing, making synthetics, solving a problem, making a decision, and investigating the evidence. While in the control group, the learning activities and assessments are oriented on the handbook. In the learning process, the students are focused on the topics given in their handbook and directed toward the researcher's explanation. Some of the more dominant and participative in the learning process, but most of them are passive. The finding shows that both groups had a significant difference. It can be said that the experimental group was better than the control group. The fact is known from the materials, scores, and activities used in the experimental group that support students' interest in learning more about Grammar topics. Meanwhile. It is different from the activities of the control group that can not be effective because the teacher explanation dominated the activities.

Finally, teaching Grammar by using CTL is effective as interesting activities, because CTL is a versatile and simple method for improving students' English learning

Imam Nur Aziz, Yuli Ani Setyo Dewi

The Implementation of Contextual Teaching and Learning on English Grammar Competence
(88)

http://e-journal.ikhac.ac.id/index.php/alsuna https://doi.org/10.31538/alsuna 
comprehension. It also made students active and cooperative with their friends to find the problem solutions so that they can increase their competence in learning English, especially in mastering and practicing grammar materials.

\section{Conclusion}

Based on the result of the counting after analyzing the data, it is found out that $F$ value $(8,7)$ is higher than F critical score $(6,96)$ with $\mathrm{df} 76$ at 0,01 level of significance. This gives an interpretation that the null hypothesis $\left(\mathrm{H}_{0}\right)$ is rejected and the alternative hypothesis $\left(\mathrm{H}_{\mathrm{a}}\right)$ is accepted. So, it shows that the students who are taught using CTL have a better score than those who are taught using the conventional method. Finally, this means that the contextual teaching and learning (CTL) method is more effective than the conventional method in teaching grammar.

Contextual teaching and learning (CTL) in teaching grammar gives an occasion for grammar learners to practice the material they get and relate it to the real-world situation. In this case, their brains will respond to the material they learn in their real context or experience actively. The brain will work to look for and to find the meaning, and then it is served in the form of practicing and acting. So, the students who are taught by using CTL learn the grammar material and they are engaged in the learning process actively. It is more meaningful learning because it is fastened upon real life and taught communicatively. CTL does not only create active learners but also makes they are able to produce and construct new grammar material they get by finding the meaning and understanding of their experience. CTL also provides the learners who do not memorize what the teacher considers but also create meaningful and interesting learning realistically.

Imam Nur Aziz, Yuli Ani Setyo Dewi

The Implementation of Contextual Teaching and Learning on English Grammar Competence
(89)

http://e-journal.ikhac.ac.id/index.php/alsuna https://doi.org/10.31538/alsuna 
On the other hand, although the average pre-test scores of both two groups are almost similar, in the treatment section, their distinctive in getting the grammar material is evident. It is proven when the treatment process is carrying out in both the experimental and control group. During the treatment of CTL, the students of the experimental group are looked very enthusiastic, interactive, active and skilled. The students in the experimental group try to construct their comprehension in getting the served materials by looking for, finding and analyzing using their critical and creative thinking. Based on the student-centered approach that is used in implementing CTL method, students are challenged to solve the problem they get in the material by themselves. They work together in searching for the solving of the problem in grammar material and they feel enthusiastic.

Then, the students of the control group only accept the grammar material from the teacher's explanation which is based on their handbook (LKS). So, their attention is only focused on the teacher's description in front of the class. It is because the approach that is used in implementing the conventional method is teacher-centered. Therefore, their English comprehension is only limited in the scope of their handbook that the teacher uses to explain them. In the classroom of the experimental group, the activity and assessment of the students are based on the other ways or procedures that are meaningful and interesting. One of them is that the teacher gives some authentic instructions. In this case, the students are given a text which is made based on their experience. Then, students are asked to read, find, and analyze the formula, pattern, and usage of sentences in the text which use the tenses of the grammar topic. Then, they are asked to search, find, and illustrate the conclusion about the topic and also find the meaning and aim of sentences on the text and relate it to their life context. Then, every student is asked to make some

Imam Nur Aziz, Yuli Ani Setyo Dewi

The Implementation of Contextual Teaching and Learning on English Grammar Competence
(90)

http://e-journal.ikhac.ac.id/index.php/alsuna https://doi.org/10.31538/alsuna 
sentences about the grammar topic based on their daily experience and also unite them into a simple paragraph. And they have to analyze the formula of the sentences they create by themselves. After that, the students are divided into some small groups to work together and understand the passage of the grammar topic. And every group has to make questions about the grammar topic, which they do not understand while the teacher answers and explains the questions by giving examples based on students' daily context or real experience. On the other hand, the other group has to listen to the other groups' questions and answers about the topic well. And the last, the students review and resume the answer to their own events, experiences, and activities orally in front of the class.

While in the classroom activity of the control group, the activity, and assessment of the students are based on their handbook. In this case, the instruction procedures are felt monotonous, flat, boring and interest less. A part of them gives attention to a flat sight, and other parts of the play and talk or disturb their friends. Indirectly, it notices that their concentration gets contaminated with their boring condition. So, this phenomenon makes students are not able to develop and practice their knowledge in learning grammar well. Knowing the different conditions of both two groups as above, it is able to make a point that the students who are taught using Contextual. Here, the finding of the research shows that both of the two groups have a significant difference. It interprets that the students' achievement of the experimental group is better than the control group. This conclusion is proven from the materials, scores, and activities used in the experimental group that produces some interesting and meaningful learnings for students in learning the grammar material. On the other hand, the learning activities in the control group are not effective because the activities are only focused on the teacher's explanation.

Imam Nur Aziz, Yuli Ani Setyo Dewi

The Implementation of Contextual Teaching and Learning on English Grammar Competence
(91)

http://e-journal.ikhac.ac.id/index.php/alsuna https://doi.org/10.31538/alsuna 
Finally, teaching grammar by using contextual teaching and learning (CTL) method is decelerated as an effective, interesting, and meaningful learning because CTL constructs students' skill in searching, finding, and analyzing the materials, and then relating them to their experience to be practiced. So, improving and developing students' grammar comprehension is not difficult when this method is applied in the language learning process, especially in teaching grammar. Based on the data analysis, this study concludes that Contextual Teaching and Learning method is more effective than the conventional method to teach grammar for the seventh grade of Junior High School Bahrul Ulum Menganti Gresik in the academic year of 2016/2017. On the other hand, teaching grammar as the research problem in this research is still general and it needs to be limited so that the objective of the study can be achieved clearly and specifically, and so that it will not be extended. So, the researcher took a limitation in teaching grammar. And the rule of grammar the researcher took for doing treatment in this research is about the material of simple future tense and all its contents. So, the study is specific to the discourse of simple future tense.

Imam Nur Aziz, Yuli Ani Setyo Dewi

The Implementation of Contextual Teaching and Learning on English Grammar Competence
ALSUNA Vol. 2 (2), 2019

http://e-journal.ikhac.ac.id/index.php/alsuna https://doi.org/10.31538/alsuna 


\section{Bibliography}

Amalia, Eka Rizki. “Developing English Textbook Material for Islamic Primary Education Program: A Participatory Action Research." ALSUNA: JOURNAL OF ARABIC AND ENGLISH LANGUAGE, vol. 1, no. 2, 2018, pp. 69-77.

Aziz, Imam Nur. “Curriculum Development of KKNI at English Education Department of INKAFA Gresik." Jalie, vol. 2, 2017, p. 3.

---. “Developing English Reading Book For College Students of INKAFA Based on Monitoring Strategy." JALIE; Journal of Applied Linguistics and Islamic Education, vol. 2, no. 2, 2019, pp. 279-304.

Baker, Elaine DeLott, et al. “Contextualized Teaching \& Learning: A Promising Approach for Basic Skills Instruction." Research and Planning Group for California Community Colleges (RP Group), ERIC, 2009.

Berns, Rg, and Pm Erickson. "Contextual Teaching and Learning: Preparing Students for the New Economy." The Highlight Zone Research, no. 5, 2001, pp. 1-8.

Brown, H. Douglas. Teaching By Principles: An Interactive Approach to Language Pedagogy. 2nd ed., longman, 2000.

Chen, Peng, and Carsten Schmidtke. "Humanistic Elements in the Educational Practice at a United States Sub-Baccalaureate Technical College." International Journal for Research in Vocational Education and Training, vol. 4, no. 2, 2017, pp. 117-45, doi:10.13152/IJRVET.4.2.2.

Elaine B, Johnson. Contextual Teaching Learning. Corwin Press, Inc, 2002.

Ertmer, Peggy A., and Timothy J. Newby. “Behaviorism, Cognitivism, Constructivism: Comparing Critical Features from an Instructional Design Perspective." Performance Improvement Quarterly, vol. 6, no. 4, Wiley Online Library, 1993, pp. 50-72.

Imam Nur Aziz, Yuli Ani Setyo Dewi

The Implementation of Contextual Teaching and Learning on English Grammar Competence
(93)

http://e-journal.ikhac.ac.id/index.php/alsuna https://doi.org/10.31538/alsuna 
Faridi, Abdurrachman. “The Development of Context-Based English Learning Resources for Elementary Schools in Central Java." Excellence in Higher Education, vol. 1, 2010, pp. 23-30, doi:10.5195/ehe.2010.13.

Fitriani, N. R., et al. "The Effectiveness of Ctl Model Guided Inquiri-Based in the Topic of Chemicals in Daily Life to Improve Students' Learning Outcomes and Activeness." Jurnal Pendidikan IPA Indonesia, vol. 5, no. 2, State University of Semarang, 2016, pp. $278-83$.

Gudu, BO. “Teaching Speaking Skills in English Language Using Classroom Activities in Secondary School Level in Eldoret Municipality, Kenya." Journal of Education and Practice, vol. 6, no. 35, 2015, pp. 55-63.

Hakim, Lukmanul. “Analisis Perbedaan Antara Kurikulum KTSP Dan Kurikulum 2013.” Didaktika, vol. 17, no. 2, 2017, pp. 280-92, doi:10.22373/jid.v16i1.590.5.

Jones, M. Gail, and Laura Brader-Araje. "The Impact of Constructivism on Education: Language, Discourse, and Meaning." American Communication Journal, vol. 5, no. 3, 2002, pp. 1-10.

Kalchik, Stephanie, and Kathleen Marie Oertle. "The Theory and Application of Contextualized Teaching and Learning in Relation to Programs of Study and Career Pathways. Transition Highlights. Issue 2." Office of Community College Research and Leadership, ERIC, 2010.

Levy, Michael. Computer-Assisted Language Learning: Context and Conceptualization. Oxford University Press, 1997.

Marcellino, M. "ENGLISH LANGUAGE TEACHING IN INDONESIA: A CONTINUOUS CHALLENGE IN EDUCATION AND CULTURAL DIVERSITY." Teflin, vol. 19, no. 1, 2008, pp. 57-69.

Imam Nur Aziz, Yuli Ani Setyo Dewi

The Implementation of Contextual Teaching and Learning on English Grammar Competence
ALSUNA Vol. 2 (2), 2019

http://e-journal.ikhac.ac.id/index.php/alsuna https://doi.org/10.31538/alsuna 
Nurhadi, and Burhan Yasin. Pembelajaran Kontekstual (Contextual Teaching and Learning/CTL) Dan Penerapannya Dalam KBK. Pertama, Universitas Negeri Malang (UM) Press, 2004.

Rafida, Tien. “Observing Contextual Teaching and Learning on Students' Achievement in Writing Recount Text." EUROPEAN-AMERICAN JOURNALS, vol. 4, no. 9, 2016, pp. 57-68.

Richardson, Virginia. "Constructivist Teaching and Teacher Education: Theory and Practice." Constructivist Teacher Education, Routledge, 2005, pp. 13-24.

Setiawan, Imam, and Muhammad Mujtaba Mitra Zuana. “Teaching Vocabulary Using Modified Snakes and Ladders Game." ALSUNA: JOURNAL OF ARABIC AND ENGLISH LANGUAGE, vol. 1, no. 2, Institut Pesantren Kh. Abdul Chalim Pact Mojokerto, Nov. 2018, pp. 87-95, doi:10.31538/alsuna.v1i2.86.

Silviana, Dilla, and Anggi Putri. “THE USE OF JIGSAW II TECHNIQUE AND STILL PICTURES COMBINATION TO IMPROVE STUDENTS ' VOCABULARY MASTERY." Journal of English Language Teaching, vol. 2, no. 2, 2013, pp. 1-11.

Weegar, Mary Anne, and Dina Pacis. "A Comparison of Two Theories of LearningBehaviorism and Constructivism as Applied to Face-to-Face and Online Learning." Proceedings E-Leader Conference, Manila, 2012.

Yani, Ahmad. "Teachers' Incorrect Pronunciation and Its Impact on Young Learners: (A Review on Linguistic Aspects of EFL Classroom Practices)." Teylin, no. 14, 2011, pp. $179-89$.

Imam Nur Aziz, Yuli Ani Setyo Dewi

The Implementation of Contextual Teaching and Learning on English Grammar Competence
ALSUNA Vol. 2 (2), 2019

http://e-journal.ikhac.ac.id/index.php/alsuna https://doi.org/10.31538/alsuna 